\title{
Felhívás a komplexitás kezelésére a prevenciós tudományos kutatás során - cikkismertetés
}

\author{
A call to address complexity in prevention science research - \\ paper review
}

Ismerteti: $\quad$ Krakkó Ágnes $\square$

Országos Közegészségügyi Intézet

Szerzők: Lich KH, Ginexi EM, Osgood ND, Mabry PL

Megjelenés: Prevention Science. 2013;14:279-289. doi 10.1007/s11121-012-0285-2

Beküldve: 2018. 05. 14.

doi: 10.24365/ef.v59i3.309

Kulcsszavak: rendszertudomány; összetett rendszerek; prevenciós tudományos módszertan

Keywords: systems science; complex systems; prevention science methodology

\section{BEVEZETÉS}

A preventív beavatkozások által megcélzott problémák gyakran összetettek, többszintű társadalmi és környezeti összefüggések rendszerében értelmezhetők. Annak ellenére, hogy e befolyásoló tényezők jelentősége ismert, a megelőző tudomány még nem alkalmaz olyan analitikai megközelítéseket, amelyek alkalmasak lennének a rendszerek komplexitásának kielégítő vizsgálatára. A rendszertudomány feltérképezi, hogy a rendszer egyes elemei hogyan befolyásolják az egész rendszer viselkedését, illetve az elemek hogyan hatnak egymásra és a környezetükre. Jelen tanulmány fókuszában a rendszertudományi szemlélet ismertetése áll, amely hagyományos vizsgálati módszerekkel kiegészítve választ adhat a prevenciós kutatások jelenlegi kihívásaira, szem előtt tartva a vizsgálandó problémák összetettségét. A közlemény három rendszertudományi módszert szemléltet: 1. a társadalmi kapcsolatháló elemzését (social network analysis); 2. a rendszerdinamikai modellezést (system dynamics modeling); 3. az ágensalapú modellezést (agent-based modeling).

\section{RENDSZERTUDOMÁNY}

Az összetett rendszerek definícióját illetően még nincs egyetértés, de a legtöbb meghatározás alapján az egymással kölcsönhatásban lévő elemek sokaságát (rendszerét) jelenti, amelyben a rendszer egészének a tulajdonságait és viselkedését nem lehet meghatározni a rendszer egyes elemeinek a tulajdonságaiból és viselkedéséből, vagy a külön-külön vizsgált elemek tulajdonságainak és viselkedésének az összegéből. A rendszertudományi módszer lehetővé teszi a rendszer elemei közötti dinamikai kapcsolat vizsgálatát, amellyel a több szinten érvényesülő elemzésen túl egyidejüleg a rendszer viselkedése teljes egészében tanulmányozható. Rendszernek nevezhetjük például az egészségügyi rendszert vagy a társadalmat, de olyan tényezők összességét is, amelyek hatással vannak például az immunrendszer múködésére, a tuberkulózis terjedésére egy adott populációban vagy akár a kábítószer-használatra. Jellemző az összetett rendszerekre, hogy az elemek között kétirányú, nemlineáris kapcsolat van, az intervenciókra adott válaszként pedig önszerveződés vagy 
adaptáció figyelhető meg (a rendszeren belül az elemek válasza a rendszer más területein bekövetkező változásokra).

\section{A RENDSZERTUDOMÁNY SZEREPE A PREVENCIÓS KUTATÁSOKBAN}

A prevenciós kutatás komplexitásait nagyrészt redukcionista megközelítéssel vizsgálják, amellyel megbízható módon és részletesen feltárhatók a rendszer minden egyes elemének tulajdonságai. A többszintű statisztikai megközelítésekkel csak korlátozottan ismerhetjük meg, hogy az egyéni szinten bekövetkező változások hogyan hatnak a rendszer magasabb szintjeire (pl. szomszédság, iskola, lakosság). Mi több, az egyéni elemek (pl. egyének) közötti összetett dinamikai kapcsolat és az egyes elemek változásai (pl. eltérő szokások családi és iskolai környezetben) sem kerülnek meghatározásra. Ha kizárólag a redukcionista módszerekre támaszkodunk, akkor előfordulhat, hogy nem látjuk a részletektől az egészet, és ez akadályozhatja a rendszer viselkedésének megismerését. A hagyományos redukcionista módszerek nem alkalmasak arra, hogy a többszörös interaktív változókat egy egész rendszerként vizsgáljuk velük, és az összetett időbeli dinamika feltárására sem (például a kapcsolatok időbeli változása vagy a rendszer nem várt viselkedése). E tényezők vizsgálatára a rendszertudományi módszerek megfelelőek, amelyek jól leírják a rendszer emergens viselkedését, ami azt jelenti, hogy a rendszerszintű viselkedés nem vezethető le a rendszer alkotóelemeinek egyes tulajdonságaiból. A rendszerhatások (system effects) megértése segít megismerni a rendszer viselkedését, így lehetővé teszi a sokkal hatékonyabb és fenntarthatóbb többszintû beavatkozások kidolgozását. Egy hatékonyabb intervenciót szolgáló rendszer megértése - mint kezdeti befektetés - megtérülhet, mivel a rendszertudományi modellek hosszú távon használhatók, így folyamatosan elősegíthetik például a rendszerfolyamatokra vonatkozó hipotézisek megfogalmazását, hatékonyabb ellenőrzési és irányítási stratégiák kialakítását, jelentős hiányosságok meghatározását és a hatékonyabb reagálást a dinamikai problémákra. A rendszertudományban használatos szimulációs modell megfigyelése például a vizsgálatot végzők számára pontosabb képet ad arról, hogy a rendszer mennyire változik különböző körülmények között (például bizonyos környezeti feltételek mellett vagy bizonyos populációkban), és lehetőséget biztosít a valós világban lévő nehézségek hatékonyabb meghatározására (idő, költség, kivitelezés). A prevenciós kutatásokban a rendszertudományi módszerek használata az innováció elősegítése céljából olyan módszerek kidolgozására ösztönözhet, amelyek elősegítik például az érdekeltek konszenzusra jutását a szakpolitikai lehetőségek priorálását illetően, az intervenciós célpontok sikeres meghatározását, vagy akár a sikeres beavatkozási mechanizmusok tulajdonságainak tanulmányozását.

\section{A RENDSZERTUDOMÁNY KULCSFOGALMAI}

A rendszertudomány könnyebb megértését három illusztratív módszer bemutatása teszi lehetővé. Ezeket a módszereket időnként abból a célból használják, hogy a komplex rendszereket érintő problémákat tanulmányozzák vagy ezeket közvetlenül optimalizálják. A rendszertudomány eszközei olyan betekintést tesznek lehetővé, amelyek elősegítik a hatékonyabb beavatkozást és kontrollt valós, komplex rendszerekkel. Három fontos rendszertudományi módszer kap egyre nagyobb hangsúlyt az egészségügy területén: a társadalmi kapcsolati háló elemzése, rendszerdinamikai modellezés, ágensalapú modellezés.

\section{A kapcsolati háló elemzése}

A kapcsolatháló-elemzés egy adott rendszer elemei - például különböző egyének, közösségi csoportok, iskolák, egyéb szervezetek - közötti kapcsolatok vizsgálatát jelenti. A módszer segít a kutatóknak megérteni a vizsgált hálózatok struktúráját (a rendszert alkotó elemek kapcsolatát) és az emergens tulajdonságaikat, amelyek a struktúrának köszönhetően alakulhatnak ki. A számítógépes szoftverek a hálózati adatok részletes elemzésével lehetővé teszik a kapcsolatok vizuális megjelenítését, amely segíthet annak megértésében, hogy az egymással kapcsolatban lévő elemeket tartalmazó komplex rendszerek hogyan viselkednek és ezek milyen módon kontrollálhatók. 


\section{Rendszerdinamikai modellezés}

A rendszerdinamikai modellezést az egészségügy számos területén alkalmazzák. A modellezés során egyéni entitásokat (emberek) vagy folyamatos mennyiségi változókat (életévek száma, elköltött pénz vagy annak a valószínúsége, hogy egy fiatal szerhasználó lesz) homogén csoportokba gyűjtenek, melyeket később egy egységként kezelnek. A rendszer elemei közötti kapcsolat vizsgálatát követően matematikai egyenletet írnak a kapcsolatok számszerúsítésére. A mérés és tesztelés után a modellt mozgásba hozzák a rendszer viselkedésének dinamikai változásait szimulálva. A szenzitivitási teszt lehetővé teszi bármely paraméterváltozás hatásának becslését és a hiányzó vagy becsült adatok fontosságának meghatározását. A rendszerdinamikai megközelítéssel meghatározhatjuk a rendszer viselkedésének okait és a beavatkozási pontokat (leverage points). Ezeknek a pontoknak az ismeretében egy rendszeren belül beavatkozhatunk, hogy változást idézzünk elő. A megközelítés két kulcsfontosságú eszközt használ: oksági diagram (causal loop diagram) és áramlás-állomány diagram (stock and flow simulation model). Az oksági diagramot a változók közötti kapcsolatok, kapcsolatokból látható visszacsatolási mechanizmusok és a rendszer viselkedésének azonosítására alkalmazzák. Az áramlás-állomány modell az állományok változásait szimulálja egy rendszeren belül bizonyos idő alatt (pl. a szerhasználat szempontjából veszélyeztetett fiatalok száma, vagy annak a valószínúsége, hogy egy fiatal nem biztonságos szexuális kapcsolatot létesít bizonyos idő alatt).

\section{Ágensalapú modellezés}

Az ágensalapú modellezésben az ágensek az egyének vagy entitások (emberek, szervezetek) leegyszerűsített replikái egy mesterséges (számítógépes) környezetben megjelenítve. A modellezés során meghatározzák a valószínúségi szabályokat, amelyek alapján az egyéni, heterogén ágensek viselkednek, egymásra hatnak, alkalmazkodnak azzal a céllal, hogy a valós világot a legszembetûnőbb módon tükrözzék. A modellezés során az ágensek kölcsönhatásba lépnek egymással és a szabályok szerint múködnek a virtuális világban. A modellezés kimenetét képezi az egyes ágensek bizonyos idő alatt megfigyelt viselkedése, és a rendszer egységként történő viselkedése. A módszer segítségével meghatározható, hogy egy feltételezhető rendszer bizonyos elemei hogyan vezetnek többszintű (társadalmi-gazdasági) jelenség kialakulásához. Heterogén ágensek szimulálása révén képes nyomon követni minden egyes ágens viselkedését és a környezethez való adaptációit (válasz a környezetre).

\section{TANULSÁGOK A HAZAI SZAKEMBEREK SZÁMÁRA}

Az ismertetésben a rendszertudományi szemlélet fontossága, alkalmazásának előnyei és lehetőségei kerültek bemutatásra a prevenció területén. A rendszertudományi szemlélet átfogó módszer, a prevenciós tudomány kérdéseinek többszintű aspektusát képes megcélozni, mert figyelembe veszi a vizsgálandó problémák összetettségét, kontextusát, dinamikai jellegét és rendszerszintű viselkedését. Ezáltal a rendszertudományi megközelítés a prevenciót elősegítő intervenciók tervezésére, kivitelezésére és értékelésére alkalmas módszernek bizonyul. A módszer a modelleket egyértelmúbbé teszi a vizsgálatot végzők számára, ezzel a különböző érdekeltek feltételezései és gondolatai átláthatóbbá válnak, és a problémáról kialakítható egy közös nézet. A cikk bemutatásának célja tehát, hogy a módszert minél szélesebb körben megismerjék, a hagyományos vizsgálati módszereket a szakemberek kiegészítsék a rendszertudományi megközelítésekkel, amelyek sokkal részletesebb megfigyelést tesznek lehetővé. 